\title{
Can Payments for Ecosystem Services Contribute to Adaptation to Climate Change? Insights from a Watershed in Kenya
}

\author{
$\underline{\text { Isabel van de Sand }}^{1,2,3}, \underline{\text { John K. Mwangi }}^{4,5}$ and Sara Namirembe ${ }^{6}$
}

\begin{abstract}
Climate change presents new challenges for the management of social-ecological systems and the ecosystem services they provide. Although the instrument of payments for ecosystem services (PES) has emerged as a promising tool to safeguard or enhance the provision of ecosystem services (ES), little attention has been paid to the potential role of PES in climate change adaptation. As an external stressor climate change has an impact on the social-ecological system in which PES takes place, including the various actors taking part in the PES scheme. Following a short description of the conceptual link between PES and adaptation to climate change, we provide practical insights into the relationship between PES and adaptation to climate change by presenting results from a case study of a rural watershed in Kenya. Drawing upon the results of a participatory vulnerability assessment among potential ecosystem service providers in Sasumua watershed north of Nairobi, we show that PES can play a role in enhancing adaptation to climate change by influencing certain elements of adaptive capacity and incentivizing adaptation measures. In addition, trade-offs and synergies between proposed measures under PES and adaptation to climate change are identified. Results show that although it may not be possible to establish PES schemes based on water utilities as the sole source of financing, embedding PES in a wider adaptation framework creates an opportunity for the development of watershed PES schemes in Africa and ensures their sustainability. We conclude that there is a need to embed PES in a wider institutional framework and that extra financial resources are needed to foster greater integration between PES and adaptation to climate change. This can be achieved through scaling up PES by bringing in other buyers and additional ecosystem services. PES can achieve important coadaptation benefits, but for more effective adaptation outcomes it needs to be combined with vulnerability assessments and climate scenarios to ensure that these are realized and potential trade-offs between PES measures and adaptation measures minimized.
\end{abstract}

Key Words: adaptation; climate change; climate variability; payments for ecosystem services; watershed

\section{INTRODUCTION}

The instrument of payments for ecosystem services (PES) has become increasingly popular, especially in the context of developing countries, given its potential to contribute to the sustainable use of natural resources and poverty reduction. Although much of the literature has focused on the potential impacts of PES on the poor (e.g., Suyanto et al. 2007, Bulte et al. 2008), the connection between PES and adaptation to climate variability and change has only recently begun to receive attention.

Whereas the conceptual link between PES and adaptation to climate variability and change has been made in two recent articles (van de Sand 2012a, Wertz-Kanounnikoff et al. 2011), in this article we aim to provide some practical insights into the relationship, drawing upon a case study of a rural watershed in Central Kenya. Given the need for adaptation and the fact that PES schemes in Africa are only beginning to emerge, gaining practical insights into the relationship between PES and adaptation as well as synergies and trade-offs between the two is important for further development of PES-schemes in Africa.

We show that implementation of a PES incentive mechanism between Nairobi City Water and Sewerage Company (NCWSC) and farmers to adopt soil and water conservation strategies can have positive cobenefits and reduce vulnerability to climate variability and change for both ecosystem service (ES) providers and buyers. However, financial constraints on the part of NCWSC and the current institutional set up of the water sector in Kenya hinder the establishment of a direct PES scheme between NCWSC and farmers in the watershed. At the same time, some of the current and potential strategies implemented by farmers to deal with climate variability and change have potential negative effects on the provision of ecosystem services, which need to be addressed. PES needs to be embedded in a wider institutional framework and more financial resources made available to foster integration between PES and adaptation to climate variability and change.

\section{LINK BETWEEN PES AND ADAPTATION TO CLIMATE VARIABILITY AND CHANGE}

PES has been described as "a voluntary transaction where a welldefined ES (or a land-use likely to secure that service) is being 'bought' by a (minimum one) ES buyer from a (minimum one) ES provider if and only if the ES provider secures ES provision" (Wunder 2005:3). The system in which PES is taking place can thus be understood as the coupled social-ecological system, made

\footnotetext{
${ }^{1}$ Department for International Development (DFID), London, UK, ${ }^{2}$ former Researcher at the German Development Institute / Deutsches Institut für Entwicklungspolitik (DIE), Bonn, Germany, ${ }^{3}$ former Research Fellow at the World Agroforestry Centre (ICRAF), Nairobi, Kenya, ${ }^{4}$ Jomo Kenyatta University of Agriculture and Technology, Nairobi, Kenya, ${ }^{5} \mathrm{PhD}$ Fellow, World Agroforestry Centre (ICRAF), Nairobi, Kenya, ${ }^{6}$ World Agroforestry Centre (ICRAF), Nairobi, Kenya
} 
up of the interaction between providers and buyers of ES on the one hand, and land use and management practices made by providers that influence ES provision. Climate change can be expected to alter the provision of ecosystem services and to have a direct impact on the social actors involved. A PES system is thus potentially sensitive to impacts of climate change, but could also influence the ability of providers and buyers to deal with the impacts of climate variability and change.

Adaptation to climate variability and change is understood as "Adjustment in natural or human systems in response to actual or expected climatic stimuli or their effects" (IPCC 2007:869). In this article "adaptation" refers to adaptation expected to reduce vulnerability (Smit and Wandel 2006) to climate variability and change. Adaptation can include increasing adaptive capacity and implementing measures to reduce the impacts of climatic hazards (Adger et al. 2005, Füssel and Klein 2006). Adaptive capacity involves the asset base or preconditions necessary to implement strategies to deal with climate variability and change (Adger and Vincent 2005, Nelson et al. 2007 as cited in Brown et al. 2010) and is often characterized with the help of the five capitals: human, social, natural, financial, and physical.

Figure 1 presents a framework linking PES and adaptation (van de Sand 2012a), modified for the local level, where many watershed PES mechanisms operate and where buyers and providers are often located at the same spatial scale. Drawing upon the concepts of vulnerability, adaptive capacity and adaptation, the framework depicts three main ways through which PES and adaptation positively interlink: by influencing provision of ecosystem services, by influencing the different elements of adaptive capacity and by providing an incentive mechanism for ecosystem service providers to adopt specific measures for adaptation to climate change.

Fig. 1. Framework showing the link between payments for ecosystem services (PES), adaptation, and vulnerability of the coupled social-ecological system. Source: based on van de Sand (2012a)

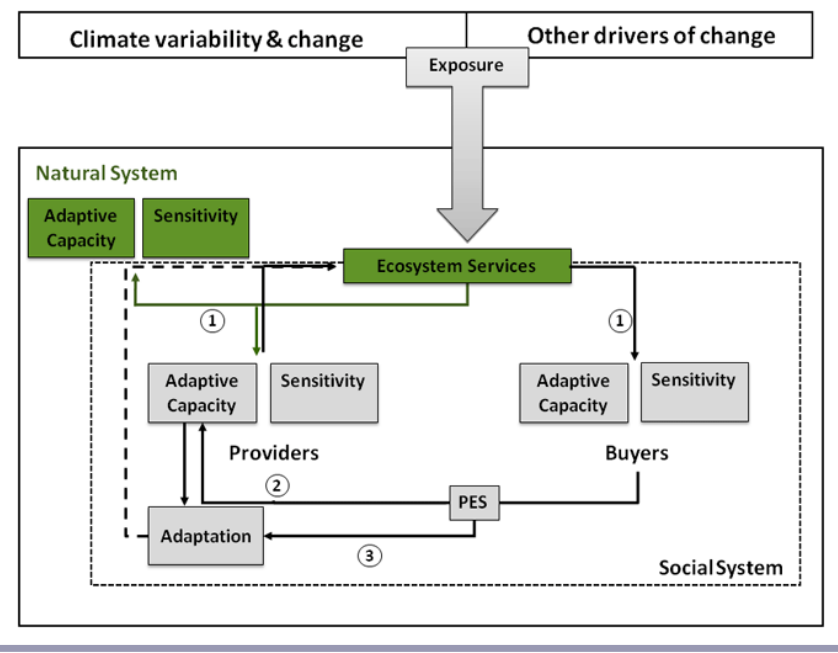

The most direct link between PES and adaptation is demonstrated if there is an overlap between required adaptation measures and provision of ecosystem services. In addition, PES could contribute to increasing elements of adaptive capacity. For example, monetary payments have potential to increase financial capital, while in-kind payments, e.g., provision of drought resistant seeds, can enhance physical capital and/or contribute to the direct implementation of certain adaptation strategies. To what extent PES is able to achieve this depends on a number of factors, which influence adaptation (Adger et al. 2004). These include availability of resources necessary for implementation of adaptation strategies, recognition of the need for adaptation, the belief that adaptation is possible and desirable, and a willingness to undertake adaptation. On the other hand, there could be potential trade-offs between implementation of certain measures to deal with climate variability and change and the provision of ES, and between PES measures and adaptation measures, respectively. These need to be taken into account to avoid PES contributing to maladaptation or adaptation measures undermining the long-term viability of the PES scheme.

\section{Analyzing linkages between watershed PES and adaptation to climate change in practice}

The framework was applied to a watershed PES scheme in Sasumua, Kenya, to address the following questions:

- What are the impacts of climate variability and change on ecosystem service buyers, providers, and ecosystem services provision?

- Is there a perceived need for adaptation among ecosystem service buyers and providers?

- Is there synergy between required adaptation measures and PES?

- Are there potential trade-offs between adaptation and PES strategies? How can these be minimized?

- Are the resources generated through PES sufficient to fund PES and any additional adaptation measures?

- What are the implications for the future design of PES schemes?

Several reasons influenced the choice of location of the study: First, Africa is regarded as being particularly vulnerable to impacts of climate change (Boko et al. 2007, UNFCCC 2010) and also suffers from degradation in the provision of ecosystem services (UNEP 2006). Second, watershed PES is particularly sensitive to impacts of climate variability and change through impacts on the hydrological cycle. Furthermore, compared to other forms of PES schemes, providers and buyers of watershed services tend to be located on the same spatial scale, which facilitates analysis in terms of identification of actors and impacts (Pagiola and Platais 2007, as cited in Turpie et al. 2008). 


\section{DESCRIPTION OF THE CASE STUDY AREA: SASUMUA WATERSHED}

Sasumua watershed $\left(107 \mathrm{~km}^{2}\right)$ is located in Kinangop District of Nyandarua County in the humid and subhumid zones of Central Kenya $\left(36.58^{\circ}\right.$ and $36.68^{\circ}$ east and $0.65^{\circ}$ and $0.78^{\circ}$ south), approximately $90 \mathrm{~km}$ north of the capital Nairobi (Fig. 2; Gathenya et al. 2009). The population is predominantly rural and poor, mainly cultivating potatoes, cabbages and carrots.

The watershed supplies approximately $15-20 \%$ of Nairobi's potable water, with some areas in the city relying exclusively on it (Neacsu 2003, Drops of life... 2008, Sangira and Mango 2008). The NCWSC operates a treatment plant and reservoir inside the watershed from where water is channeled to Nairobi.

The watershed has historically been considered a wet place with above average annual rainfall (van de Sand 2012b). However, in recent years, low rainfall and incidences of drought have affected the growing population of farmers and NCWSC. The company is extremely vulnerable to fluctuations in rainfall and is frequently forced to ration water because it cannot satisfy the demand (Water rationing in Nairobi... 2008). The situation was exacerbated in 2003 when heavy rains caused the collapse of the dam spillway (Floods leave... 2003, Kumba 2008, Water rationing in Nairobi... 2008, Sangira and Mango 2008) reducing its storage capacity from 16 million $\mathrm{m}^{3}$ to around 7 million $\mathrm{m}^{3}$ (P. Githinji, Dam Coordinator, Sasumua Dam, 2009, personal communication; P. Mwaura, Dam Coordinator, 2009, personal communication). Although rehabilitation of the dam in 2011 restored its original storage capacity, current water demand for Nairobi $\left(650,000 \mathrm{~m}^{3} /\right.$ day) is still higher than the available supply $\left(482,940 \mathrm{~m}^{3} /\right.$ day; Gathura 2010, Kumba 2010, Mungai et al. 2011).

Unsustainable land use practices in parts of the watershed result in degradation of natural vegetation, soil erosion, and siltation (van de Sand 2012b), and affect the operations of NCWSC, which relies wholly on surface water to fill the reservoir. To address this, the Pro-Poor Rewards for Environmental Services in Africa (PRESA) project, in the World Agroforestry Centre (ICRAF), conducted research to support the development of a PES scheme between upland farmers (ecosystem service providers) and NCWSC. Proposed soil conservation measures (SCM) include grassed waterways and grass filter strips to control soil erosion, thus providing water purification and regulation ecosystem services. The NCWSC can benefit from these interventions in terms of reduced expenditure on water treatment and more regulated flow and is thus a potential buyer of ecosystem services.

\section{METHODS}

To address the questions raised above, a combination of approaches was used. Workshops were conducted among ES providers in five different parts of the watershed to analyze perception of climate variability and extremes, need for adaptation, current status of adaptive capacity and current adaptation strategies. The first series of workshops focused on climate variability and extremes, its impact and response strategies in addition to covering general trends and problems that occurred in the watershed. They were attended by a total of 69 farmers. Results were discussed in a joint workshop with representatives from all areas. The second series of workshops analyzed adaptive
Fig. 2. Location of Sasumua watershed.
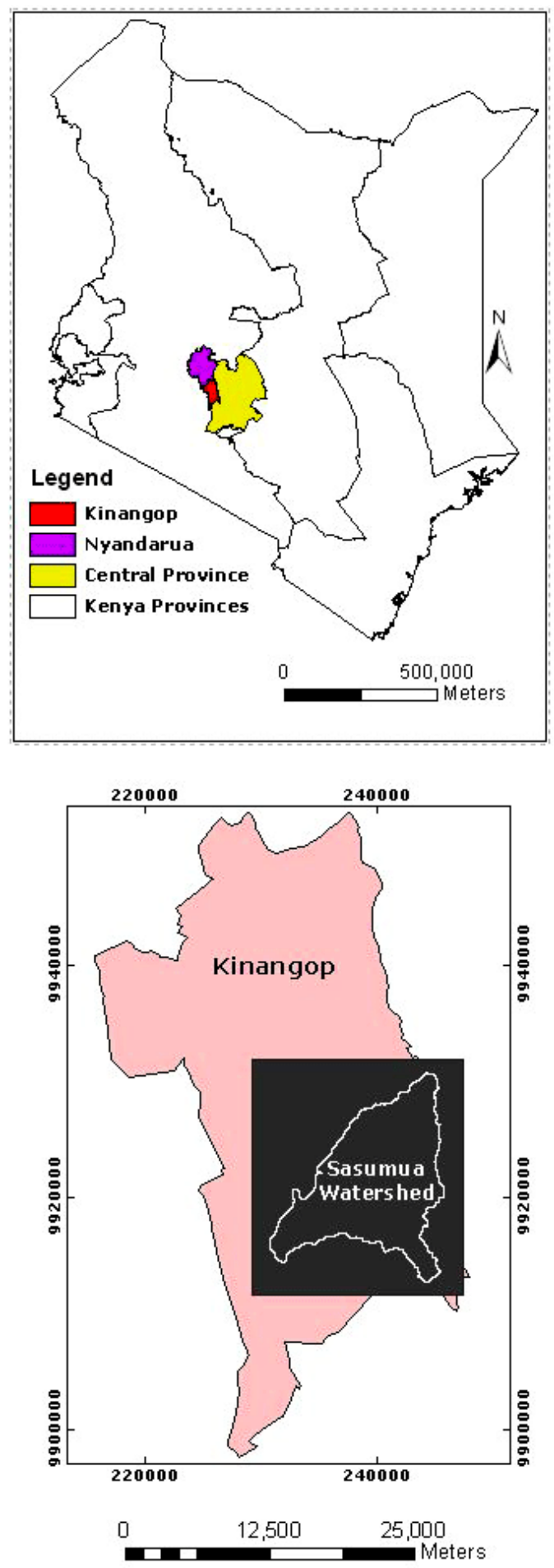
capacity in more depth and identified adaptation options to increase adaptive capacity and were attended by a total of 48 farmers. The workshops used participatory rural appraisal techniques (including trend and change analysis for key variables over the past 50 years using trend lines and matrixes, seasonal calendar and problem-ranking) together with focused group discussions to analyze exposure to climatic events, assess adaptive capacity, evaluate current coping strategies, and identify adaptation measures. The information gathered from farmers was discussed with local government officials. It was then triangulated with literature sources and meteorological data. Further details about the methodology used can be found in van de Sand (2012b). This provided the basis to identify synergies and trade-offs between adaptation strategies identified by farmers to deal with climate variability and change, and proposed measures to be implemented under the PES scheme.

The impact of climate variability and change on NCWSC and on ecosystem service provision (improved water quality and quantity) was assessed through hydrological modeling using a range of climate change scenarios as given by downscaled Global Climate Change Models (GCMs). These included a high rainfall and low temperature scenario; and a low rainfall and high temperature scenario. In addition, an extremely dry year scenario and a scenario simulating increased precipitation intensity were simulated to reflect changes in extremes. Downscaled climate change projections were obtained from the Climate Information Portal of the Climate Systems Analysis Group of the University of Cape Town for Nyeri station, which lies approximately $40 \mathrm{~km}$ to the east of the watershed, but showed similar seasonal variations in rainfall as Sasumua dam station located inside the watershed. Scenarios were used for the emission scenario A2 and the time period of 2046-2065. These were applied to the control period (1971-2000) for which daily meteorological data was available from three stations within the watershed. To choose between different model projections and prepare the data available from the downscaled climate change projections for input into the hydrological model, broadly the approach described by Tadross and Wolski (2010) was followed, which uses percentile changes from different GCMs to capture model range. Of the 10 GCMs provided by the Climate Information Portal, two were removed because of discrepancies between simulated and observed data. For simulating changes in rainfall intensity, the high rainfall (90th percentile of rainfall) and low temperature (10th percentile of minimum and maximum temperature) was modified by applying the projected increase in rainfall only to the three days in the month with the highest rainfall, as suggested by Prudhomme et al. (2002). For the scenario of an extremely dry year, the year 2000 was chosen based on observed past meteorological records for three stations inside the watershed.

Downscaled projections of GCMs were incorporated in the hydrological modeling, using the perturbation method as outlined by Prudhomme et al. (2002). The hydrological model used was the Soil and Water Assessment Tool (SWAT), developed by the U.S. Department of Agriculture's Agricultural Research Service in the early 1990s. SWAT allows modeling of climate, and impacts of land and water management on water, sediment, and agricultural chemical yields (Arnold and Fohrer 2005) in agricultural watersheds. It has been widely used to study effects of climate variability and change on watersheds in various parts of the world (e.g., Boorman 2003, Xu et al. 2009, Sridhar and Nayak 2010, Bae et al. 2011, Liu et al. 2011). To evaluate the perceived need for adaptation and identify adaptation options for the ecosystem service buyer, results from a vulnerability assessment of NCWSC to climate change conducted by the World Bank were drawn upon (Danilenko et al. 2010) and complemented with an interview with the dam coordinator at Sasumua dam.

The potential for PES to increase financial capital of farmers was estimated by comparing the opportunity costs of farmers for implementing soil conservation measures with the cost savings gained by the NCWSC through improvements in water quality. Opportunity costs were derived from a willingness to accept a survey among farmers in the watershed that had been conducted by PRESA (Mwangi et al. 2011), whereas cost savings were derived from the hydrological modeling and expenditure data on water treatment by the NCWSC. From these expenditures potential savings on the part of NCWSC from improved land management were estimated and these were taken as the funds available for implementing PES.

\section{RESULTS}

\section{Impact of climate variability and change on ecosystem service providers}

Climate change and unreliable rainfall were ranked among the top four problems perceived by farmers in three out of five areas in the watershed. Results from the timeline showed that farmers in the watershed experienced a number of extreme events including dry spell, drought, frost, and heavy rainfall leading to floods, which negatively impacted crop and livestock production (Table 1). In addition, farmers identified delayed onset and early onset of the rainy season and strong winds as climatic events that are negatively affecting their agricultural production. Because farmers are dependent on rainfall for agricultural production, they are particularly sensitive to changes in rainfall patterns. Through trend analysis farmers identified a decrease in the amount of rainfall over the past 50 years, which they further described in terms of a reduction in the number of rainy days: "Nowadays, you get rain for 2-3 days, then sun for a week, before rain used to fall continuously. Nowadays, you have more days of sun than rain," and a reduction in the amount of rainfall and in the duration of the short (October, November, December), and long rainy season (March, April, May): "We used to expect the short rains and the long rains. Now the rainfall has reduced, so even for the long rains we experience it for a shorter time." Statistical analysis of meteorological data confirmed farmers' perceptions in terms of reductions in the amount, duration, and number of rain days during the long rains, whereas trends for the short rains could not be confirmed (van de Sand 2012b).

\section{Adaptation measures by farmers}

Although farmers have employed a number of strategies to cope with these events (Table 2), not all of them are deemed to be effective (van de Sand 2012b). In addition, farmers are aware of additional strategies (Table 3), but lack of knowledge, finances, and technology currently prevent them from implementing these. Knowledge, finances, and technology were also identified as 
Table 1. Climate related events and their impacts identified by farmers during timeline analysis.

\begin{tabular}{|c|c|c|}
\hline Year & Event & Impact \\
\hline \multirow[t]{2}{*}{1960} & Heavy rains (heavier than El Niño) & Joblessness \\
\hline & & Hunger \\
\hline \multirow[t]{2}{*}{1964} & Floods & Joblessness \\
\hline & & Hunger \\
\hline 1972 & Frost ("Mbaa”) & Destruction of trees and crops \\
\hline \multirow[t]{5}{*}{1978} & Heavy rains & Collapse of chania bridge affecting transport and communication \\
\hline & Invasion of locust & Flooding leading to destruction of crops \\
\hline & & Crop diseases \\
\hline & & High milk production \\
\hline & & Low food availability \\
\hline \multirow[t]{2}{*}{1980} & Dry spell & Famine ("Ng'aragu") \\
\hline & & Relief food was distributed \\
\hline \multirow[t]{2}{*}{ 1984-1985 } & Outbreak of foot and mouth disease & Famine ("Ng'aragu") \\
\hline & $\begin{array}{l}\text { Frost ("Mbaa") with high intensity } \\
\text { Prolonged dry spell }\end{array}$ & Migration of Masai into the watershed to search for food and pasture \\
\hline \multirow[t]{4}{*}{$1997-1998$} & El Niño & Floods \\
\hline & & Soil erosion \\
\hline & & Crop damage \\
\hline & & Hunger \\
\hline \multirow[t]{5}{*}{2003} & Heavy rains & Floods \\
\hline & & Collapse of Sasumua dam wall \\
\hline & & Shortage of water in storage and thus water shortage in Nairobi \\
\hline & & Crop damage \\
\hline & & Soil erosion, leading to soil infertility \\
\hline \multirow[t]{5}{*}{2008} & Drought & Death of animals \\
\hline & & Shortage of water \\
\hline & & Major reductions in crop yield \\
\hline & & Relief food was distributed \\
\hline & & $\begin{array}{l}\text { Migration into the watershed from outside because of post election violence and because } \\
\text { people were moving in to search for food }\end{array}$ \\
\hline
\end{tabular}

critical components of adaptive capacity that need enhancement (Table 4). There is thus a high perceived-adaptation need.

\section{Adaptation measures with potential negative impacts on} watershed ecosystem service

Some of the strategies shown in Table 2 have potential negative impacts on water quality and quantity. Although farmers regard the application of agro-chemicals as an effective strategy to deal with pests and diseases, they described that their increased use over the past 50 years as depicted in the trend analysis contributed to water pollution, which according to them also increased over the past 50 years. Farmers attributed this to the increased occurrence of pests and diseases as a result of rising temperatures. Although current dry season water quality assessments did not detect critical levels of pesticides (Gathenya et al. 2009), further increases in temperature are likely to increase the use of agrochemicals with potential negative consequences for water quality.

Another common strategy is to take cattle for grazing in the forest and other open grassland areas within the watershed in times of fodder shortages. Overgrazing can lead to soil compaction due to cattle trampling, resulting in increased surface runoff, soil erosion (e.g., Descroix et al. 2008), and a negative effect on water quality. Illegal grazing in the forest has, in fact, been identified as a critical source of siltation by NCWSC and as an issue that needs to be addressed in a recent report on sustainable management of the
Aberdare Conservation Area (Mungai et al. 2011), parts of which are adjacent to the Sasumua watershed.

Abstraction of water from Sasumua River was also cited as a measure to deal with water shortages in the low lying areas of the watershed. This may reduce the amount available for NCWSC, which is already faced with increased competition for water with inhabitants of the watershed.

Synergies between adaptation measures, ecosystem service provision, and soil conservation measures implemented under PES

Soil conservation has been identified as an important strategy by farmers to deal with heavy rainfall events leading to floods (Table 3). Soil quality was also identified as an important element of adaptive capacity that needs enhancement to deal with climate variability and other extreme events such as droughts (Table 4). However, soil conservation measures are not yet widely implemented because of financial constraints, lack of knowledge and skills.

Impact of climate variability and change on NCWSC

NCWSC identified climate change as a major problem and considered itself "very vulnerable" to decreased surface water quantity and "somewhat vulnerable" to more concentrated and earlier water flows (World Bank 2012). As shown in Table 5, 
Table 2. Farm management practices currently used by farmers to deal with climate variability and extremes.

\begin{tabular}{|c|c|}
\hline Farm Management Practices & Climatic Event \\
\hline Applying chemicals to deal with crop disease & Heavy rainfall leading to flood, delayed onset of the rainy season \\
\hline Planting hedges as windbreaks & Wind, frost \\
\hline Walking long distances to fetch water from rivers & Drought, delayed onset of the rainy season \\
\hline Digging wells deeper & Dry spell \\
\hline Veterinary treatment to deal with diseases in livestock & Delayed onset of the rainy season, heavy rainfall leading to flood, \\
\hline Buying fodder for livestock & Delayed onset, drought, heavy rainfall leading to flood, frost \\
\hline Grazing livestock in forest/open areas of the watershed & Frost, heavy rainfall leading to flood \\
\hline $\begin{array}{l}\text { Digging channels, dams, and trenches to remove water from agricultural } \\
\text { fields }\end{array}$ & Heavy rainfall leading to flood \\
\hline Borrowing seeds & Heavy rainfall leading to flood \\
\hline Reducing number of livestock & Drought, delayed onset of the rainy season, dry spell \\
\hline Reducing number of farm inputs & Drought \\
\hline Restock livestock & Frost \\
\hline Harvesting rainwater & Drought \\
\hline Substitute fertilizer with manure & Drought \\
\hline
\end{tabular}

climate change has differential impacts on water yield, sediment yield, and concentration. Scenarios 1 and 4, which simulate high increases in rainfall and increased intensity of rain, show an increase in water yield by about $41 \%$, and an increase in sediment yield by about $75 \%$ and $104 \%$, respectively. The lower rainfall scenario and the scenario of an extremely dry year, on the other hand, show a reduction both in water and sediment yield. However, most of the scenarios show increases in sediment concentration implying increased water treatment costs, except for the extremely dry year. Although the company has implemented a number of adaptation strategies (Table 6) it does not consider itself adequately prepared to deal with impacts of climate change (World Bank 2012), suggesting that there is a high adaptation need on the part of the NCWSC.

\section{Adaptation measures by NCWSC}

Climate adaptation measures by NCWSC (Table 6) include activities geared toward watershed protection, such as monitoring changes and improving watershed management by discouraging encroachments and using vegetation to recharge groundwater aquifers and improve the quality of surface water. This shows there is a high degree of awareness about implementing watershed protection measures as adaptation strategies. The company has, for example, planted over 100,000 tree seedlings in the riparian areas under its control (Danilenko et al. 2010). It has, however, not made any PES agreements with farmers for implementing SCMs on their private lands.

\section{Potential for PES to address NWSC management and climate variability challenges}

Implementation of SCMs by farmers in the whole watershed could result in reduced annual sediment concentration $(63-70 \%)$ and inflow to the reservoir $(70-75 \%$ reduction $)$, but would not have much effect on water yield (Table 7). For the extremely dry year, SCMs would cause great reductions in annual sediment yield and concentrations (90\% and $89 \%$, respectively) and slight increases in water inflow. Although the effect on water yield is small, analysis at a monthly level for scenarios 2 and 4 further shows that some of the increases occur during the critical dry months of the year (January, June, July, August) thus showing positive adaptation benefits (Figs. 3, 4).

Although implementation of SCMs would lessen the impact of climate change, for scenarios 1 and 4 sediment concentrations are at $285 \mathrm{mg} / \mathrm{l}$ and $309 \mathrm{mg} / \mathrm{l}$ substantially higher than under baseline conditions ( $207 \mathrm{mg} / \mathrm{l})$. This suggests that SCMs might need to be adjusted in future, e.g., by implementing additional measures, such as terraces or agroforestry, if costs are to remain constant or reduced over time.

Results suggest that implementing SCMs under PES will have direct positive adaptation benefits for both ecosystem service buyers and providers because the ecosystem services provided through PES corresponds to expressed adaptation needs for both. However, are the savings to be generated through PES sufficient to establish the PES scheme and could they be used to finance additional measures for adaptation?

\section{Costs of implementing the PES scheme}

The ICRAF PRESA project estimated the costs for implementing grass filter strips and a grassed waterway, which amount to US\$929,000 in the first year (Table 8). This includes the opportunity cost of farmers setting aside land for conservation purposes of US\$938 per ha per year (Mwangi et al. 2011), and costs of establishing grass filter strips (US\$312.5/ha), and a grassed waterways ( $\$ 1281.5$ per $\mathrm{km})$.

Opportunity costs of farmers (US\$214,990) exceed the cost savings of NCWSC through improved water quality. The company currently spends US $\$ 300,000$ per year on chemicals for water treatment representing the cost of purchasing chemicals and a further US\$50,000 per year for desilting clogged water intakes (Mwangi et al. 2011). Assuming that reductions in sediment flow and concentration resulting from implementation of SCMs in the parts of the watershed under agriculture would result in a proportionate reduction in costs of buying chemicals, a cost saving of around US\$196,835 per year can be achieved from $65 \%$ reduction in sediment concentration. 
Fig. 3. Differences in water inflow (above), sediment yield (middle), and sediment concentration (below) with and without best management practices (BMPs) for Scenario 2.

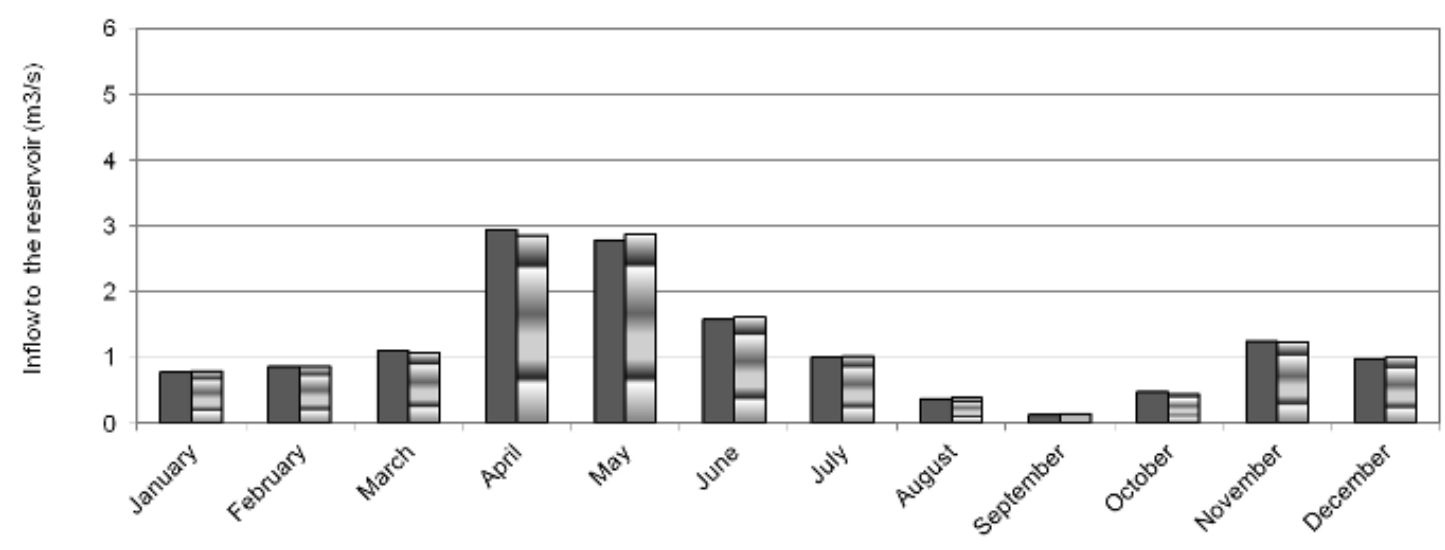

awithout BMPs 日with BMPs

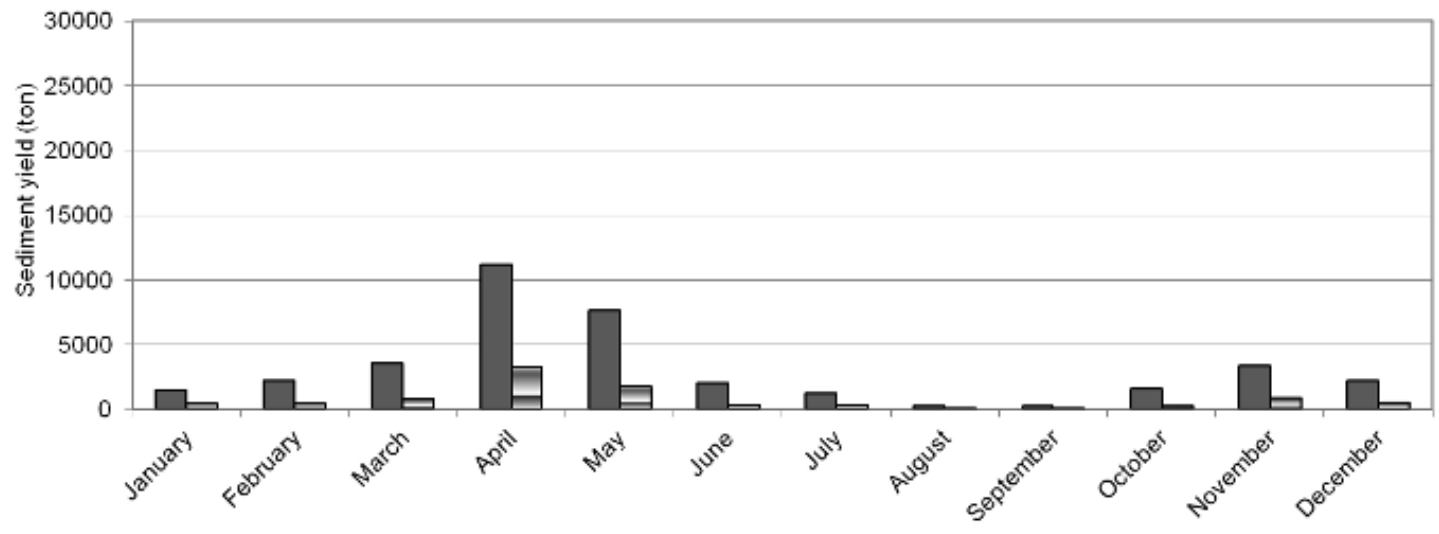

awithout BMPs awith BMPs

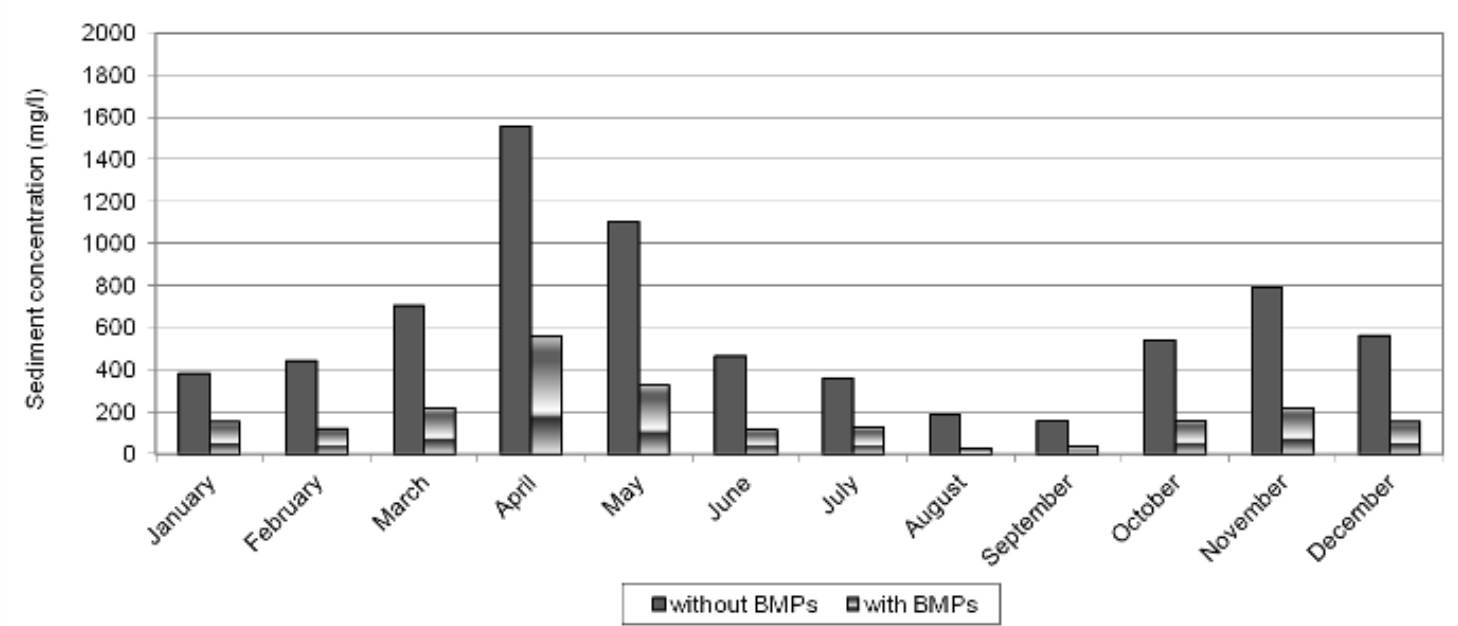


Fig. 4. Differences in water inflow (above), sediment yield (middle), and sediment concentration (below) with and without best management practices (BMPs) for Scenario 4.

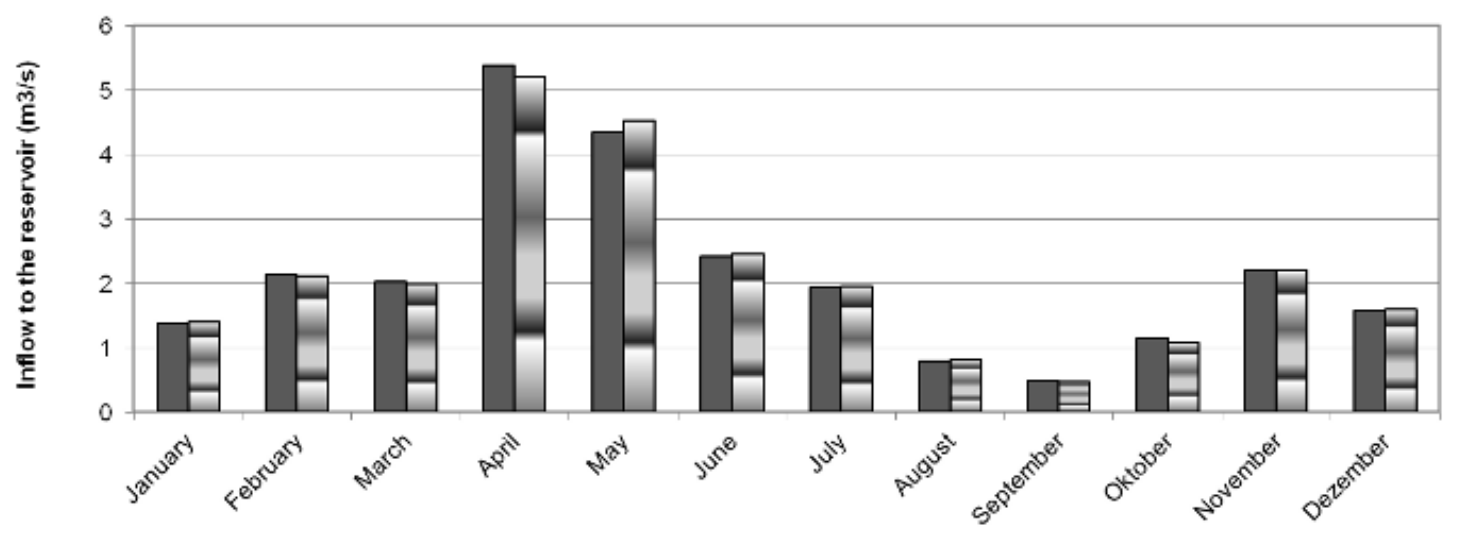

awithout BMPs घwith BMPS

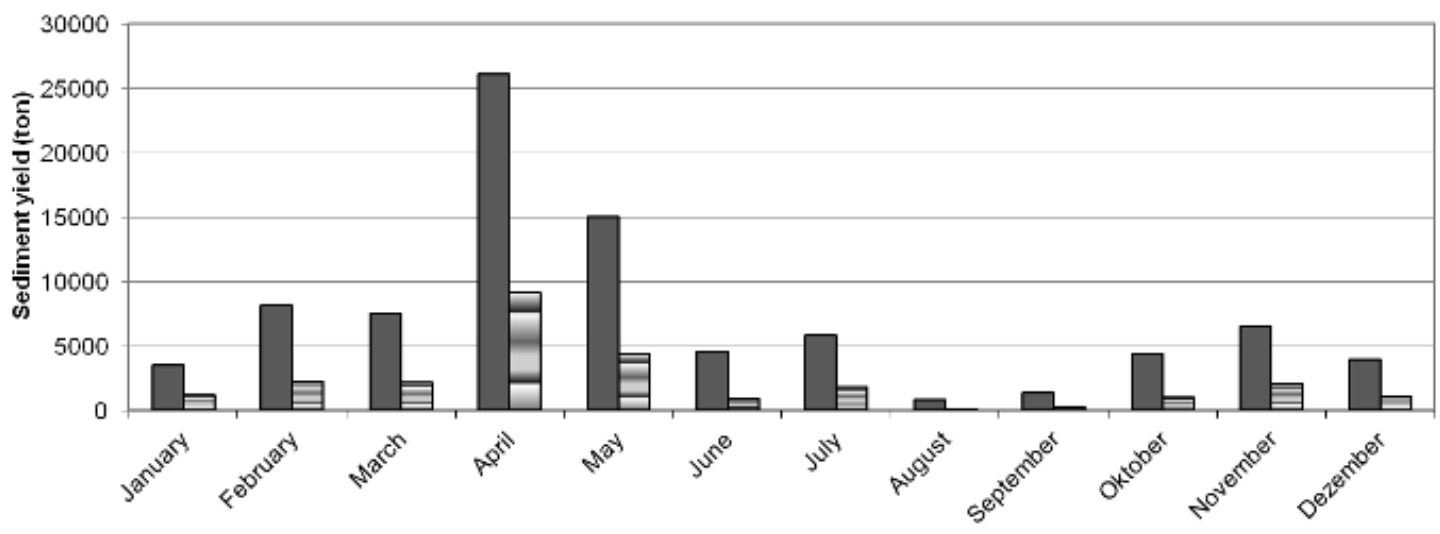

口without BMPs $\square$ with BMPs

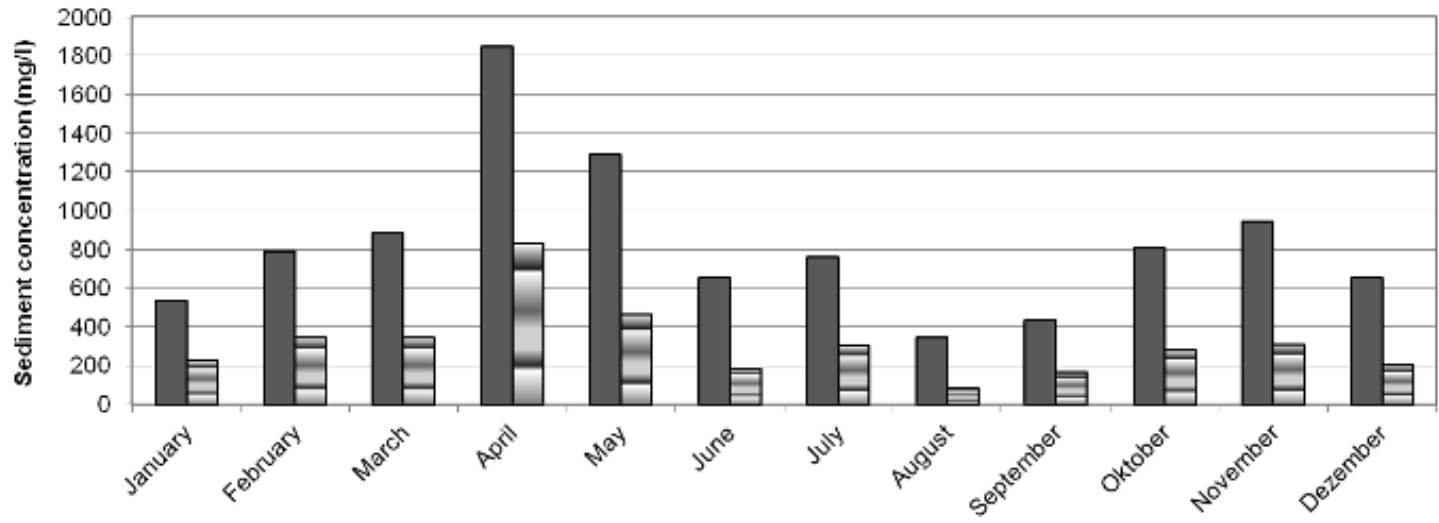

口without BMPs 日with BMPs 
Table 3. Farm management practices known to farmers to deal with climate variability and extremes, but which are not yet widely implemented.

\begin{tabular}{|c|c|c|}
\hline Farm Management Practices & Climatic Event & Constraints \\
\hline Zero-grazing & Frost & $\begin{array}{l}\text { Lack of knowledge } \\
\text { Lack of finances } \\
\text { Lack of labor }\end{array}$ \\
\hline $\begin{array}{l}\text { Planting different varieties of crops/engage in mixed } \\
\text { farming }\end{array}$ & Early onset of the rainy season, drought & $\begin{array}{l}\text { Lack of finances } \\
\text { Lack of technology } \\
\text { Lack of water } \\
\text { Ignorance }\end{array}$ \\
\hline Sprinkling crops with water to prevent frost damage & Frost & $\begin{array}{l}\text { Lack of water } \\
\text { Lack of finances }\end{array}$ \\
\hline Irrigating crops & Drought & $\begin{array}{l}\text { Lack of water } \\
\text { Lack of finances } \\
\text { Lack of technology } \\
\text { Lack of knowledge }\end{array}$ \\
\hline Establishing greenhouses & Wind, frost, heavy rainfall leading to flood & $\begin{array}{l}\text { Lack of finances } \\
\text { Lack of skills } \\
\text { Lack of knowledge } \\
\text { Lack of water } \\
\text { Lack of technology }\end{array}$ \\
\hline Digging ponds and wells & Heavy rainfall leading to flood, drought & $\begin{array}{l}\text { Lack of finances } \\
\text { Soil structure } \\
\text { Laziness } \\
\text { Small land sizes } \\
\text { Lack of knowledge }\end{array}$ \\
\hline Storing fodder/silage making & Frost, drought & $\begin{array}{l}\text { Lack of knowledge } \\
\text { Lack of finances } \\
\text { Lack of storage facilities } \\
\text { Lack of materials to store fodder } \\
\text { (polythene bags) }\end{array}$ \\
\hline Buying water tanks & Drought & Lack of finances \\
\hline Buying seeds in advance to store & Early onset of the rainy season & Lack of finances \\
\hline $\begin{array}{l}\text { Join community water projects that provide tapped } \\
\text { water }\end{array}$ & Drought & $\begin{array}{l}\text { Poor leadership/Corruption within } \\
\text { management } \\
\text { Previous failure of other projects } \\
\text { Lack of water } \\
\text { Ignorance }\end{array}$ \\
\hline Drilling boreholes & Drought & Lack of finances \\
\hline Contour farming & Heavy rainfall leading to flood & $\begin{array}{l}\text { Lack of knowledge } \\
\text { Lack of skills } \\
\text { Small land sizes }\end{array}$ \\
\hline Constructing gabions and terracing & Heavy rainfall leading to flood & $\begin{array}{l}\text { Lack of knowledge } \\
\text { Lack of finances } \\
\text { Small land sizes } \\
\text { Limited willingness }\end{array}$ \\
\hline Agroforestry & Heavy rainfall leading to flood & $\begin{array}{l}\text { Lack of knowledge } \\
\text { Lack of skills } \\
\text { Small land sizes }\end{array}$ \\
\hline Investing in better livestock breeds & Drought & $\begin{array}{l}\text { Lack of finances } \\
\text { Lack of knowledge }\end{array}$ \\
\hline Planting drought resistant crops & Drought & $\begin{array}{l}\text { Lack of finances } \\
\text { Lack of technology } \\
\text { Ignorance }\end{array}$ \\
\hline $\begin{array}{l}\text { Expanding area of agricultural production } \\
\text { Using machinery (tractors) }\end{array}$ & $\begin{array}{l}\text { Drought } \\
\text { Early onset of the rainy season }\end{array}$ & $\begin{array}{l}\text { Shortage of land } \\
\text { Lack of finances } \\
\text { Small land sizes }\end{array}$ \\
\hline
\end{tabular}




\section{DISCUSSION}

Implementing soil conservation under PES would address a number of climate change adaptation needs that farmers in Sasumua mentioned, both in terms of increasing adaptive capacity and implementing adaptation measures to deal with heavy rainfall events leading to floods. Although some soil conservation strategies are already being implemented, there are wide areas in the watershed to which it could be expanded. However, lack of knowledge, skills, and finances currently prevent a wider adoption of soil conservation strategies.

Farmers are willing to accept payment to implement SCM to address both their livelihood and adaptation interests and to generate ES for NWSC through a PES agreement. Preliminary analysis, however, shows that on the one hand, opportunity costs for engaging in PES are high for farmers while cost savings of NCWSC are low in the short term. Opportunity costs for farmers are likely to decline in the long run given expected productivity gains that result from the establishment of these practices (Branca et al. 2011). Indirectly, PES will also lead to reduction in current strategies that farmers use to cope with/adapt to climate variability and change that have negative effects on ES. By providing an additional source of fodder, the implementation of grass filter strips can potentially reduce pressure on forests and other grassed areas within the watershed. This is likely to have positive effects on the provision of other ecosystem services, such as biodiversity and landscape beauty.

PES can improve adaptive capacity of farmers by providing finances and increasing agricultural productivity through increased soil quality and by providing and additional source of fodder in the long run. The impact on the financial capital element of adaptive capacity, however, depends not only on whether payments made are above the opportunity costs, but also on whether the finances are adequately used. Farmers have low financial management skills as was revealed from discussions with farmers and government officials. There is thus a need to accompany payments with training in financial management to ensure a long lasting impact on financial capital. Furthermore, the timing and manner of cash distribution is likely to affect adaptive capacity in various ways. Making payments through bank accounts rather than through direct cash payments may reduce spending on undesired items, as money is less readily available (Gaarder et al. 2010, Gertler 2011). Regarding the timing of payments, the months of greatest stress are January and early September, when school fees have to be paid and August when food, fodder, and water availability are low. During those months need for credit is high. Aligning payments to these periods of the year is thus likely to have additional positive effects on the other elements of adaptive capacity, such as human capital, if payments are used to enhance education and nutrition.

NWSC downstream, which is incurring heavy recurrent costs of water treatment could potentially benefit from SCM. Furthermore, results have shown that the implementation of SCM would substantially reduce the impacts of different climate change scenarios and increase water yield during critical dry periods of the year, thus addressing its long-term adaptation
Table 4. Example for the rating of adaptive capacity conducted for drought in the lower lying areas of the watershed. Ratings were conducted on a scale of 1(very bad current state/very low priority of action to improve the current state of indicators) to 5 (very good current state/very high priority of action) and broadly followed the approach outlined by Roth et al. (2010) and Brown et al. (2010).

\begin{tabular}{|c|c|c|c|c|}
\hline & \multicolumn{2}{|c|}{ Men } & \multicolumn{2}{|c|}{ Women } \\
\hline & $\begin{array}{c}\text { Current } \\
\text { state }\end{array}$ & $\begin{array}{c}\text { Priority of } \\
\text { action }\end{array}$ & $\begin{array}{c}\text { Current } \\
\text { state }\end{array}$ & $\begin{array}{c}\text { Priority of } \\
\text { action }\end{array}$ \\
\hline \multicolumn{5}{|l|}{ Human capital } \\
\hline Knowledge & 3 & 4 & 3 & 5 \\
\hline Health & 3 & 5 & 3 & 4 \\
\hline $\begin{array}{l}\text { Positiveness/ } \\
\text { willingness to save } \\
\text { the problem }\end{array}$ & 2 & 5 & 2 & 2 \\
\hline Commitment & 1 & 4 & 3 & 5 \\
\hline Skills & 1 & 5 & 2 & 4 \\
\hline Average & 2 & 4.6 & 2.6 & 4 \\
\hline \multicolumn{5}{|l|}{ Social Capital } \\
\hline Welfare groups & 3 & 5 & 2 & 4 \\
\hline $\begin{array}{l}\text { Cooperative } \\
\text { societies }\end{array}$ & 1 & 4 & 1 & 5 \\
\hline Friends & 2 & 4 & 2 & 3 \\
\hline Church groups & 4 & 5 & 1 & 4 \\
\hline Family & 2 & 5 & 2 & 4 \\
\hline Average & 2.4 & 4.6 & 1.6 & 4 \\
\hline \multicolumn{5}{|l|}{ Natural Capital } \\
\hline Tree cover & 3 & 5 & 2 & 3 \\
\hline Soil quality & 2 & 5 & 2 & 5 \\
\hline Livestock & 3 & 5 & 3 & 3 \\
\hline Forest & 3 & 5 & 1 & 4 \\
\hline River & 1 & 2 & 2 & 3 \\
\hline Average & 2.4 & 4.4 & 2 & 3.6 \\
\hline \multicolumn{5}{|l|}{ Physical captial } \\
\hline Farm inputs & 3 & 5 & 3 & 5 \\
\hline $\begin{array}{l}\text { Water tanks, dams } \\
\text { wells, ponds }\end{array}$ & 3 & 5 & 3 & 4 \\
\hline Buildings & 5 & 4 & 3 & 4 \\
\hline Roads & 2 & 5 & 3 & 5 \\
\hline Greenhouse & 1 & 5 & 2 & 4 \\
\hline Average & 2.8 & 4.8 & 2.8 & 4.4 \\
\hline \multicolumn{5}{|l|}{ Financial capital } \\
\hline Funds & 3 & 5 & 2 & 4 \\
\hline Savings & 2 & 5 & 1 & 5 \\
\hline Bank account & 2 & 4 & 2 & 4 \\
\hline Security assets & 2 & 4 & 3 & 5 \\
\hline $\begin{array}{l}\text { Employment in } \\
\text { agriculture }\end{array}$ & 3 & 5 & 3 & 4 \\
\hline Average & 2.4 & 4.6 & 2.2 & 4.4 \\
\hline
\end{tabular}


Table 5. Water and sediment yield into Sasumua reservoir under baseline and different climate change scenarios.

\begin{tabular}{lccccc}
\hline \hline & Baseline & $\begin{array}{c}\text { Scenario 1 (high } \\
\text { rainfall and low } \\
\text { temperature) }\end{array}$ & $\begin{array}{c}\text { Scenario 2 (low rainfall } \\
\text { and high temperature) }\end{array}$ & $\begin{array}{c}\text { Scenario 3 } \\
\text { (Extremely dry year } \\
-2000)\end{array}$ & $\begin{array}{c}\text { Scenario 4 (high rainfall, low } \\
\text { temperature, and increased } \\
\text { intensity of rain) }\end{array}$ \\
\hline $\begin{array}{l}\text { Inflow to the reservoir } \\
\text { (m3/s) }\end{array}$ & 1.53 & 2.15 & 1.17 & 0.37 \\
$\begin{array}{l}\text { Percentage change } \\
\text { compared to baseline }\end{array}$ & 43,165 & $71.07 \%$ & $-23.36 \%$ & $-75.91 \%$ & 4.15 \\
$\begin{array}{l}\text { Sediment inflow (ton/yr) } \\
\text { to the reservoir }\end{array}$ & 75,702 & 36,360 & 8817 & $88.58 \%$ \\
$\begin{array}{l}\text { Percentage change as } \\
\text { compared to baseline }\end{array}$ & 600.91 & $75.38 \%$ & $-15.76 \%$ & $-79.57 \%$ & 821 \\
$\begin{array}{l}\text { Sediment concentration } \\
\text { in mg/l }\end{array}$ & 782.80 & 604.65 & 405.62 & $825.92 \%$ \\
$\begin{array}{l}\text { Percentage change as } \\
\text { compared to baseline }\end{array}$ & $30.27 \%$ & $0.6 \%$ & $-32.5 \%$ & $37.39 \%$ \\
\hline
\end{tabular}

needs. However, for NWSC to engage in a direct buyer-provider relationship with farmers in the watershed it must see PES as a good business investment. The preliminary analysis in this paper looking at only the potential for some SCM on water treatment costs shows that on a financial basis alone, there is no short-term incentive for NWSC to engage. The ability of NCWSC to finance PES for reasons other than cost-savings, e.g., corporate social responsibility, is limited because the NCWSC is currently running close to its operating cost (Joffe et al. 2008, World Bank 2012). NWSC engagement is also constrained by institutional hurdles. This is because under the Water Act of 2002, NCWSC pays water abstraction fees to the Water Resource Management Authority (WRMA; Msafiri 2008), which is mandated to "manage and protect water catchments" (Republic of Kenya 2002:13). Under the current set up utility companies consider PES a double payment above the statutory levies. However, although payments are made for watershed services, they are not necessarily invested back in the watershed. The willingness and ability of NCWSC to finance PES thus seems to be limited.

Given the expected long-term adaptation benefits for both ecosystem service buyers and providers and the fact that opportunity costs for farmers are likely to decline in future, there is a strong case for implementing PES despite the fact that cost savings of NCWSC are not enough to do so in the short term. There are various options to achieve this.

\section{Options to raise additional funds for PES and climate change adaptation}

Raising additional funds on the beneficiaries side

Additional funds for PES could be raised in two ways. The first option would require institutional reform, so that part of water abstraction fees paid by NCWSC is retained for use within the catchment. As WRMA is mandated to protect water catchments, these funds could be used to finance additional adaptation measures with positive benefits for ecosystem services, e.g., agroforestry measures in farmers' fields to reduce pressure on the forested parts in the watershed. This will supplement the SCMs to be financed through NCWSC.
A willingness to pay for analysis conducted as part of the PRESA project involving 200 water consumers from areas served by Sasumua reservoir suggests that up to $80 \%$ of consumers are willing to pay US\$3 on top of their monthly water bills to finance watershed conservation. This translates into an extra US\$575,657 per year (Balana et al. 2013). This might be another option NWSC could use to finance PES. However, increasing water tariffs requires approval from the Water Services Regulatory Board (WASREB), the body mandated to regulate water tariffs. Mandatory increases would also have to be implemented in the whole of Nairobi and it may not be in line with NCWSC propoor water pricing policy. Alternatively payments could be made through voluntary contributions and by specifically targeting industrial water users. Most of the water in Nairobi is consumed by large scale industries, such as Kenya Breweries Limited and Coca Cola Limited who could be targeted to fund watershed conservation in order to protect their business and for corporate social responsibility reasons.

Complementing PES finances with finances from other sources Some of the institutions created under the Water Act provide good opportunities for bringing in external actors for catchment management. The Water Services Trust Fund (WSTF) is a propoor public fund designated to finance water and sanitation to marginalized groups (Republic of Kenya 2002). Money from this fund could finance adaptation measures related to the provision of water services, e.g., rehabilitation of boreholes, desilting dams and ponds, and providing water tanks. This would not only benefit farmers, but also NCWSC because it would reduce the amount of water abstracted from rivers directly, thus minimizing potential water use conflicts between NCWSC and inhabitants of the watershed, which could intensify under climate change scenarios and threaten the viability of PES in the long run.

Donor support is a potential source of financing for PES and adaptation measures. Projects that have adaptation, pro-poor and ecosystem co-benefits should be attractive from a donor's point of view. Long-term involvement of donors in PES projects has, however, often been criticized as creating an over-dependence on donors as the main source of funding thus threatening the long- 
Table 6. Adaptation measures implemented by Nairobi City Water and Sewerage Company.

\begin{tabular}{l}
\hline \hline Adaptation Measures \\
\hline Reduce nonrevenue water (leakages) \\
Augment supply by building additional surface connections \\
Augment supply by extracting additional groundwater \\
Monitor changes to and improve management of watershed \\
Use vegetation to recharge groundwater/aquifers and improve quality of surface water \\
Strengthen combined-sewer overflow facilities \\
Improve interagency coordination \\
Rationalize allocation of water resources \\
Strengthen water supply network \\
Install flood barriers \\
Protect watershed by discouraging encroachments
\end{tabular}

Source: World Bank (2012)

term financial sustainability of PES schemes (e.g. Porras et al. 2008). Complementary funding from donors should therefore be restricted to early phases of the project and should cover one-off investments only.

\section{Raising additional funds through scaling up PES by bundling it with other ecosystem services}

Additional funds could also be raised by bundling watershed PES with other ecosystem services provided by the forest, grassland areas within the watershed, and the reservoir itself. The biodiversity value of the Aberdare forest, of which Sasumua watershed is part, has been estimated at US $\$ 6,75$ billion and PES has been proposed as one of the measures for sustainable conservation of the forest (Mungai et al. 2011), also because of its importance for other water catchments. In addition, Sasumua reservoir was used as a recreational site for trout fishing in the past (Adams 1975), a venture that can be revived and supported though PES payments. Furthermore, the watershed is home to a number of endemic bird species (BirdLife International 2009) that can be exploited through promotion of ecotourism. This would also ensure that some of the additional benefits, such as landscape beauty, or "side effects" (Wertz-Kanounnikoff et al. 2011) that would accrue from implementation of watershed PES measures would be captured and internalized and that the overall resilience of the natural ecosystem of which Sasumua watershed is part is strengthened by safeguarding the many ecosystem services it provides.

To foster a greater integration between PES and adaptation to climate change a combination of the different options presented above is required, embedding PES in a wider adaptation framework and involving actors from government, private sector, donors, and NGOs. In this way the potential risk of overloading PES with multiple objectives, e.g., adaptation, poverty reduction, ecosystem service provision, instead of focusing on its main objective of ecosystem service provision, a tension that is often summarized in terms of equity vs efficiency in the PES literature (see e.g., Pascual et al. 2010) is minimized. Whereas money from the NCWSC and their water consumers would be used to finance SCMs under PES, money from public sources, e.g., government of Kenya, donors, adaptation funds, would be used for financing complementary adaptation measures, start-up costs, and capacity building for adaptation. The institutional structures established under PES could hereby serve as good entry points to conduct further trainings and capacity building efforts for adaptation. As the results have shown, there is a clear need for further training for the implementation and maintenance of SCMs because lack of knowledge and skills in addition to lack of finances currently prevent farmers from adopting SCMs. The structures set up for training and capacity building for SCMs should be used to provide additional training to replace some of the strategies employed by farmers with potential negative impacts on the PES scheme in the long run (e.g., training on zero-grazing and silage making to reduce pressure on grasslands and open areas in the watershed, organic farming, fertilizer and pesticide management to maintain/ improve water quality, and water harvesting) and to increase the other elements of adaptive capacity (e.g., training on financial management, crop and livestock diversification, training on health issues). Thus by embedding PES in a wider adaptation framework the essential features of a PES scheme, i.e., conditionality, additionality, voluntary transaction, will be retained but complemented with additional finances and capacity building efforts for adaptation from other actors. This form of nested approach, in which PES financed through the private sector is embedded in a larger adaptation context, is similar to the one described by Lipper and Neves (2011), who argue for a greater integration of the public and private sectors for PES programs that promote sustainable agricultural development.

\section{Lessons learned and implications for watershed PES schemes in Africa}

Many of the challenges experienced by the PES scheme in Sasumua are similar to those discussed in the wider PES literature. High design and implementing costs (Wunder et al. 2008), particularly in Africa (Berttram 2011), are believed to be one of the main reasons why watershed type PES schemes failed to take off (Porras et al. 2008, Stanton et al. 2010). The reluctance of the private sector to engage in PES deals has also been shown in the Naivasha catchment in Kenya, where water users claim that they are already paying water user fees to WRMA (Boonstra 2010). Limited financial resources resulting from low operating cost coverage and poor financial and commercial management are a common problem faced by many sub-Saharan African water 
Table 7. Water and sediment yield into Sasumua reservoir under baseline and different climate change scenarios after implementing best management practices (BMPs).

\begin{tabular}{|c|c|c|c|c|c|}
\hline & $\begin{array}{l}\text { Baseline with } \\
\text { BMPs }\end{array}$ & $\begin{array}{c}\text { Scenario } 1 \text { (high rainfall } \\
\text { and low temperature) } \\
\text { with BMPs }\end{array}$ & $\begin{array}{c}\text { Scenario } 2 \text { (low rainfall } \\
\text { and high temperature) } \\
\text { with BMPs }\end{array}$ & $\begin{array}{c}\text { Scenario } 3 \\
\text { (Extremely dry year } \\
\text { - 2000) with BMPs }\end{array}$ & $\begin{array}{c}\text { Scenario } 4 \text { (high rainfall, low } \\
\text { temperature, and high } \\
\text { intensity of rainfall) with } \\
\text { BMPs } \\
\end{array}$ \\
\hline $\begin{array}{l}\text { Inflow to the reservoir } \\
\left(\mathrm{m}^{3} / \mathrm{s}\right)\end{array}$ & 1.53 & 2.15 & 1.17 & 0.37 & 2.15 \\
\hline $\begin{array}{l}\text { Percentage change as } \\
\text { compared to baseline/ } \\
\text { scenarios without BMPs }\end{array}$ & $-0.03 \%$ & $-0.03 \%$ & $-0.03 \%$ & $0.5 \%$ & $-0.03 \%$ \\
\hline $\begin{array}{l}\text { Percentage change as } \\
\text { compared to baseline } \\
\text { with BMPs }\end{array}$ & & $41.08 \%$ & $-23.37 \%$ & $-75.78 \%$ & $40.57 \%$ \\
\hline $\begin{array}{l}\text { Sediment inflow (ton/yr) } \\
\text { to the reservoir }\end{array}$ & 11,815 & 22,473 & 9162 & 908 & 26,769 \\
\hline $\begin{array}{l}\text { Percentage change as } \\
\text { compared to baseline } \\
\text { without BMPs/scenarios } \\
\text { without BMPs }\end{array}$ & $-72.63 \%$ & $-70.31 \%$ & $-74.80 \%$ & $-89.7 \%$ & $-69.59 \%$ \\
\hline $\begin{array}{l}\text { Percentage change as } \\
\text { compared to baseline } \\
\text { with BMPs }\end{array}$ & & $90.20 \%$ & $-22.46 \%$ & $-92.31 \%$ & $126.56 \%$ \\
\hline $\begin{array}{l}\text { Sediment concentration } \\
\text { in } \mathrm{mg} / \mathrm{l}\end{array}$ & 206.64 & 285.11 & 181.76 & 45.59 & 308.87 \\
\hline $\begin{array}{l}\text { Percentage change as } \\
\text { compared to baseline/ } \\
\text { climate change scenarios } \\
\text { without BMPs }\end{array}$ & $-65.61 \%$ & $-63.58 \%$ & $-69.94 \%$ & $-88.76 \%$ & $-62.59 \%$ \\
\hline $\begin{array}{l}\text { Percentage change as } \\
\text { compared to baseline } \\
\text { with BMPs }\end{array}$ & & $37.97 \%$ & $-12.04 \%$ & $-77.94 \%$ & $49.47 \%$ \\
\hline
\end{tabular}

utilities (Dillaha et al. 2007, Banerjee et al. 2008). Furthermore, Dillaha et al. (2007) regard poverty and low connectivity to water services as serious impediments for the further development of watershed PES in Africa.

Therefore, does that mean that watershed PES in Africa are unlikely to materialize in the future? Although it may be difficult to establish PES schemes based on water utilities as the sole source of financing, adopting an adaptation lens on PES and embedding PES in a wider adaptation framework presents an opportunity for the further development of PES schemes in Africa. In this respect, the question of whether ecosystem service beneficiaries would be willing to spend additional money on adaptation measures should be further explored. The Sasumua watershed, for example, is not only an important source of water, but also of food for the residents of Nairobi. Assisting farmers to adapt to impacts of climate change and sustain food productivity is therefore in the interest of Nairobi residents. Although WertzKanounnikoff et al. (2011) suspect that there might be a limited willingness to finance ecosystem-based adaptation through PES, other researchers suggest that this might not be the case. A survey conducted among firms in Costa Rica, for example, found that the main motivation for investing in ecosystem services included a desire to contribute to human welfare, ecological responsibility, and expected image benefits (Koellner et al. 2010). Results from a willingness to pay analysis among industrial water users in Indonesia also found willingness to pay to be strongly influenced by bequest values (van de Sand 2004). These findings suggest that contrary to economic theory underpinning the establishment of PES schemes, nonfinancial benefits might be equally important so that there might well be a motivation for financing adaptation measures in addition to the provision of ecosystem services.

\section{CONCLUSION}

In this article we have shown that by promoting environmentally benign land uses in the watershed to secure water quality, the proposed PES measures can have positive adaptation benefits for both ecosystem service providers and the main ecosystem service buyer, Nairobi City Water and Sewerage Company. Using hydrological modeling and climate change scenarios, we provided scientific evidence on the linkage between implementation of SCMs and water quality and quantity benefits for NCWSC under present day and climate change conditions, a link that is commonly missing in many watershed PES schemes (Porras et al. 2008). However, current institutional set up in the water sector and financial constraints on the part of the NCWSC hinder the establishment of a direct seller-buyer PES. Institutional reform and embedment of PES in a wider framework that includes collaboration with other actors is required to foster greater integration between PES and adaptation. PES should also be 
Table 8. Costs of implementing payments for ecosystem services (PES) measures ${ }^{\dagger}$.

\begin{tabular}{lcccc}
\hline \hline & $\begin{array}{c}\text { Per ha } \\
\text { (US\$) }\end{array}$ & $\begin{array}{c}\text { Proposed area of } \\
\text { intervention (ha) }\end{array}$ & $\begin{array}{c}\text { Total (1st year; } \\
\text { US\$) }\end{array}$ & $\begin{array}{c}\text { Maintenance/opportunity cost subsequent } \\
\text { years (US\$) }\end{array}$ \\
\hline $\begin{array}{l}\text { Willingness of farmers to accept area taken } \\
\text { out of production for conservation purposes } \\
\text { (grassed water way and grass filter strip) }\end{array}$ & 938 & 229.2 & $214,989.60$ & $214,989.60$ \\
$\begin{array}{l}\text { Implementation cost of grassed water way } \\
\text { (input, labor, maintenance; 20 km length, }\end{array}$ & $\begin{array}{c}1281.5 \text { per } \\
\mathrm{km}\end{array}$ & 1576.00 & $25,625.00$ & 3750.00 \\
$\begin{array}{l}\text { 2.5 wide and 2m walkway. Land taken out } \\
\text { of production = 9 ha) }\end{array}$ & & & & \\
$\begin{array}{l}\text { Implementation cost of grass filter strip } \\
\text { (grass, manure, and labor. Land taken out of } \\
\text { production = 220.2 ha) }\end{array}$ & 312.5 & 2202.00 & $688,125.00$ & 37.50 \\
Total cost & & & & \\
\hline
\end{tabular}

${ }^{\top}$ The technical specificities for the grassed water way and the grassed filter strips are based on Thomas et al. (1997). For deriving cost estimates, the methodology outlined in Onduru and Muchena (2011) was followed, using local prices and cost estimates derived from farmers in the watershed at the time of study.

scaled up by bringing in other buyers and additional ecosystem services, such as carbon sequestration, wildlife habitat, and landscape beauty that could be targeted for ecotourism purposes. Although making PES proadaptation involves a greater effort than establishing a normal PES scheme, harnessing synergies between PES and adaptation and embedding PES in a wider adaptation framework presents an opportunity to further advance watershed PES in Africa. For achieving more effective adaptation outcomes PES should be combined with vulnerability assessments and climate scenarios to ensure that adaptation is factored in from the beginning rather than becoming an "accidental" outcome, as described by Wertz-Kanounnikoff et al. (2011).

Responses to this article can be read online at: http://www.ecologyandsociety.org/issues/responses. $\mathrm{php/6199}$

\section{Acknowledgments:}

An earlier version of this article was presented at the Economics of Ecosystem and Biodiversity TEEB Conference 2012 in Leipzig in March 2012 and we are grateful for the feedback received from the participants of the conference. We would also like to thank Dr. Imme Scholz, Dr. Bernd Siebenhüner, and two anonymous reviewers for comments and suggestions on how to improve an earlier draft of this article. We acknowledge the financial support received from the German Federal Ministry for Economic Cooperation and Development (BMZ) and support received through the Pro-Poor Rewards for Environmental Services in Africa (PRESA) project, implemented by the World Agroforestry Centre (ICRAF), in carrying out research presented in this article. The work presented in this paper was completed while the author I. van de Sand was employed at the German Development Institute/Deutsches Institut für Entwicklungspolitik (DIE).

DISCLAIMER: The views and opinions expressed in this paper are the author's own views and do not necessarily reflect the official policy or position of the Department for International Development.

\section{LITERATURE CITED}

Adams, N. M. 1975. God rest you merry, gentlemen. The season inspires warm memories of an angling holiday at Christmas, when the Brown Trout Inn in Kenya was a haven for Englishmen far from home. Sports Illustrated, 22 December. [online] URL: http:// sportsillustrated.cnn.com/vault/article/magazine/MAG1090616/index. $\underline{\mathrm{htm}}$

Adger, W. N., N. Brooks, G. Bentham, M. Agnew, and S. Eriksen. 2004. New indicators of vulnerability and adaptive capacity. Technical Report 7, Tyndall Centre for Climate Change Research, University of East Anglia, Norwich, UK.

Adger, W. N., N. W. Arnell, and E. L. Tompkins. 2005. Successful adaptation to climate change across scales. Global Environmental Change 15:77-86. http://dx.doi.org/10.1016/j.gloenvcha.2004.12.005

Adger, W. N., and K. Vincent. 2005. Uncertainty in adaptive capacity. Comptes Rendus Geoscience 377:399-410. http://dx.doi. org/10.1016/j.crte.2004.11.004

Arnold, J. G., and N. Fohrer. 2005. SWAT2000: current capabilities and research opportunities in applied watershed modelling. Hydrological Processes 19(3):563-572. http://dx.doi. org/10.1002/hyp.5611

Bae, D.-H., I.-W. Jung, and D. P. Lettenmaier. 2011. Hydrologic uncertainties in climate change from IPCC AR4 GCM simulations of the Chungju Basin, Korea. Journal of Hydrology 401(1-2):90-105. http://dx.doi.org/10.1016/j.jhydrol.2011.02.012 
Balana, B. B., D. Catacutan, and M. Mäkelä. 2013. Assessing the willingness to pay for reliable domestic water supply via catchment management: results from a contingent valuation survey in Nairobi City, Kenya. Journal of Environmental Planning and Management 56:1511-1531. http://dx.doi.org/10.1080/09640568.2012 .732934

Banerjee, S., H. Skilling, V. Foster, C. Briceño-Garmendia, E. Morella, and T. Chfadi. 2008. Africa - Ebbing water, surging deficits: urban water supply in sub-Saharan Africa. Background Paper 12, The World Bank, Washington, D.C., USA. [online] URL: https://openknowledge.worldbank.org/handle/10986/7835

Berttram, D. 2011. Payments for ecosystem services - a feasible mechanism for natural resource management in East Africa? Taking stock and preparing to advance. Thesis, Utrecht University, Utrecht, The Netherlands.

BirdLife International. 2009. Important bird area factsheet: Kinangop grasslands, Kenya. BirdLife International, Cambridge, UK. [online] URL: http://www.birdlife.org/datazone/sitefactsheet. php?id=6394

Boko, M., I. Niang, A. Nyong, C. Vogel, A. Githeko, M. Medany, B. Osman-Elasha, R. Tabo, and P. Yamda. 2007. Africa. Pages 433-467 in M. L. Parry, O. F. Canziani, J. P. Palutikof, P. J. van der Linden, and C. E. Hanson, editors. Climate change 2007. Impacts, adaptation and vulnerability. Contribution of Working Group II to the Fourth Assessment Report of the Intergovernmental Panel on Climate Change. Cambridge University Press, Cambridge, UK.

Boonstra, M. 2010. Sustaining and enlarging the payment for watershed services (PWS) program in the Naivasha Catchment. Institute for Environmental Studies (IVM), Amsterdam, The Netherlands. [online] URL: ftp://ftp.itc.nl/pub/naivasha/vu/ Boonstra2010.pdf

Boorman, D. B. 2003. Climate, hydrochemistry and economics of surface-water systems (CHESS): adding a European dimension to the catchment modelling experience developed under LOIS. Science of The Total Environment 314-316(0):411-437. http://dx. doi.org/10.1016/S0048-9697(03)00066-4

Branca, G., L. Lipper, B. Neves, D. Lopa, and I. Mwanyoka. 2011. Payments for watershed services supporting sustainable agricultural development in Tanzania. Journal of Environment \& Development 20(3):278-302. http://dx.doi.org/10.1177/1070496511415645

Brown, P. R., R. Nelson, B. Jacobs, P. Kokic, J. Tracey, M. Ahmed, and P. DeVoil. 2010. Enabling natural resource managers to selfassess their adaptive capacity. Agricultural Systems 103 (8):562-568. http://dx.doi.org/10.1016/j.agsy.2010.06.004

Bulte, E. H., L. Lipper, R. Stringer, and D. Zilberman. 2008. Payments for ecosystem services and poverty reduction: concepts, issues, and empirical perspectives. Environment and Development Economics 13:245-254. http://dx.doi.org/10.1017/S1355770X08004348

Danilenko, A., E. Dickson, and M. Jacobsen. 2010. Climate change and urban water utilities: challenges and opportunities. Water Working Notes. Note No. 24, The World Bank, Washington, D.C., USA. [online] URL: http://water.worldbank. org/publications/climate-change-and-urban-water-utilities-challengesopportunities

Descroix, L., J.L. González Barrios, D. Viramontes, J. Poulenard, E. Anaya, M. Esteves, and J. Estrada. 2008. Gully and sheet erosion on subtropical mountain slopes: their respective roles and the scale effect. CATENA 72(3):325-339. http://dx.doi. org/10.1016/j.catena.2007.07.003

Dillaha, T., P. Ferraro, M. Huang, D. Southgate, S. Upadhyaya, and S. Wunder. 2007. Payments for watershed services regional synthesis. USAID PES Brief 7, Sustainable Agriculture and Natural Resources Management Collaborative Research Support Program, Office of International Research, Education, and Development (OIRED), Virginia Tech, Blacksburg, Virginia, USA. [online] URL: http://sanrem.cals.vt.edu/1010/

Dillaha2007 PWS regional syntheses.pdf

Drops of life: Sasumua dam. 2008. Youtube video, 4:31. Posted by NTV Kenya, 30 September. [online] URL: http://www.youtube. com $/$ watch? $=$ ru7aHSHCBB0

Floods leave Nairobi dry. 2003. BBC News, 5 May. [online] URL: http://news.bbc.co.uk/2/hi/africa/3001225.stm

Füssel, H.-M. and R. J. T. Klein. 2006. Climate change vulnerability assessments: an evolution of conceptual thinking. Climatic Change 75(3):301-329. http://dx.doi.org/10.1007/ $\underline{\mathrm{s} 10584-006-0329-3}$

Gaarder, M. M., A. Glassman, and J. E. Todd. 2010. Conditional cash transfers and health: unpacking the causal chain. Journal of Development Effectiveness 2(1):6-50. http://dx.doi.

org/10.1080/19439341003646188

Gathenya, J. M., G. T. Thiong'o, and J. K. Mwangi. 2009. Hydrologic modelling and water quality assessment of Sasumua Watershed. Technical Report, World Agroforestry Centre (ICRAF), Nairobi, Kenya. [online] URL: http://presa. worldagroforestry.org/WP-CONTENT/UPLOADS/2010/04/

Gathenya Thiongo Mwangi-Hydrological modeling water qualitytechnical report.pdf

Gathura, G. 2010. Water rationing in the middle of plenty. Daily Nation, 23 March. [online] URL: http://www.nation.co.ke/news/ Water-rationing-in-the-middle-of-plenty-/-/1056/885518/-/96voqjz/-/ index.html

Gertler, P. 2011. How CCTs can encourage investment. Presentation made at the CCT Next Generation Conference, October 24- 25 2011. World Bank, Washington, D.C., USA. [online] URL: http://siteresources.worldbank.org/

SOCIALPROTECTION/Resources/280558-1138289492561/2158434-1319815902013/PaulGertler.pdf

Intergovernmental Panel on Climate Change (IPCC). 2007. Climate Change 2007: impacts, adaptation and vulnerability: contribution of Working Group II to the fourth assessment report of the Intergovernmental Panel on Climate Change. M. L. Parry, O. F. Canziani, and J. Palutikof, editors. Cambridge University Press, Cambridge, UK.

Joffe, M., R. Hoffman, and M. Brown. 2008. African water utilities regional comparative utility creditworthiness assessment report. 
Individual credit assessment reports for seven African water utilities by Global Credit Rating Co., Water and Sanitation Program, World Bank, Nairobi, Kenya; Global Credit Rating Co, Sandton, South Africa; African Development Bank, Tunis Belvedère, Tunisia; AfWA, Abidjan, Côte d'Ivoire; PPIAF Program Management Unit, World Bank, Washington, D.C., USA.

Koellner, T., J. Sell, and G. Navarro. 2010. Why and how much are firms willing to invest in ecosystem services from tropical forests? A comparison of international and Costa Rican firms. Ecological Economics 69(11):2127-2139. http://dx.doi.org/10.1016/ j.ecolecon.2010.05.010

Kumba, S. 2008. Weather blamed for water shortage in Nairobi. Daily Nation, 1 August. [online] URL: http://www.nation.co.ke/ News/-/1056/445876/-/item/1/-/14pplrv/-/index.html

Kumba, S. 2010. City taps still dry even as rains pound the country. Daily Nation, 9 April. [online] URL: http://www.nation.co.ke/ News/regional/City+taps+still+dry+even+as+rains+pound+the+ country+/-/1070/896420/-/113063ez/-/index.html

Lipper, L., and B. Neves. 2011. Payments for environmental services. What role for sustainable agricultural development? ESA Working Paper No. 11-20, Food and Agriculture Organization of the United Nations, Rome, Italy. [online] URL: http://www.fao. org/economic/esa/publications/details/en/?dyna_fef[uid] $=148701$

Liu, L., Z. Liu, X. Ren, T. Fischer, and Y. Xu. 2011. Hydrological impacts of climate change in the Yellow River Basin for the 21st century using hydrological model and statistical downscaling model. Quaternary International 244(2):211-220. http://dx.doi. org/10.1016/j.quaint.2010.12.001

Mungai, D., T. Thenya, A. Muthee, G. Muchemi, J. K. Mworia, G. Oduori, and J. Kimani. 2011. Environmental, social and economic assessment of the fencing of the Aberdare Conservation Area. Main report., Kenya Wildlife Service, Kenya Forest Service, Kenya Forests Working Group, United Nations Environment Programme, Rhino Ark, Nairobi, Kenya.

Mwangi, J. K., J. M. Gathenya, S. Namirembe, and H. Mwangi, editors. 2011. Institutional and policy requirements for payments for watershed services in Kenya. A case study of Sasumua watershed, Kenya. PRESA Policy Brief No. 2, World Agroforestry Centre (ICRAF), Nairobi, Kenya. [online] URL: http://cap.org. za/oiddownloads1174 161207 AM PRESA Policy Brief Institutional and Policy Requirements for Payments for Watershed Services in Kenya.pdf

Neacsu, A. 2003. Keeping afloat in sunken Kenya. International Federation of Red Cross and Red Crescent Societies, Geneva, Switzerland. [online] URL: http://www.ifrc.org/en/news-andmedia/news-stories/africa/kenya/keeping-afloat-in-sunken-kenya/

Onduru, D., and F. Muchena. 2011. Cost benefit analysis of land management options in the Upper Tana, Kenya. Green Water Credits report 15, ISRIC- World Soil Information, Wageningen, Netherlands. [online] URL: http://greenwatercredits.net/sites/ default/files/documents/isric gwc report15.pdf

Pascual, U., R. Muradian, L. C. Rodríguez, and A. Duraiappah. 2010. Exploring the links between equity and efficiency in payments for environmental services: a conceptual approach. Ecological Economics 69(6):1237-1244. http://dx.doi.org/10.1016/ j.ecolecon.2009.11.004

Porras, I., M. Grieg-Gran, and N. Neves. 2008. All that glitters. A review of payments for watershed services in developing countries. Natural Resource Issues No. 11, International Institute for Environment and Development (IIED), London, UK. [online] URL: http://pubs.iied.org/13542IIED.html

Prudhomme, C., N. Reynard, and S. Crooks. 2002. Downscaling of global climate models for flood frequency analysis: where are we now? Hydrological Processes 16(6):1137-1150. http://dx.doi. org/10.1002/hyp.1054

Republic of Kenya. 2002. Act No. 8 of 2002 - Water Act. Ministry of Water and Irrigation, Nairobi, Kenya. [online] URL: http:// www.water.go.ke/index.php?option $=$ com docman \&Itemid $=89$

Roth, C., P. Brown, D. Gaydon, N. MacLeod, C. McDonald, I. Khan, and V. R. Reddy. 2010. Developing research options to mainstream climate adaptation into farming systems in Cambodia, Laos, Bangladesh and India. Final report for project LWR/2008/015 FR2010-19, Australian Centre for International Agricultural Research, Canberra, Australia. [online] URL: $\underline{\text { http:// }}$ aciar.gov.au/publication/FR2010-19

Sangira, S., and C. Mango. 2008. Water firm to relax Nairobi ration plan. Nairobi Star, 13 November.

Smit, B., and J. Wandel. 2006. Adaptation, adaptive capacity and vulnerability. Global Environmental Change 16:282-292. http://dx. doi.org/10.1016/j.gloenvcha.2006.03.008

Sridhar, V., and A. Nayak. 2010. Implications of climate-driven variability and trends for the hydrologic assessment of the Reynolds Creek Experimental Watershed, Idaho. Journal of Hydrology 385(1-4):183-202. http://dx.doi.org/10.1016/j. jhydrol.2010.02.020

Stanton, T., M. Echavarria, K. Hamilton, and C. Ott. 2010. State of watershed payments: an emerging marketplace. Ecosystem Marketplace, Washington, D.C., USA. [online] URL: http:// www.forest-trends.org/documents/files/doc 2438.pdf

Suyanto, S., N. Khususiyah, and B. Leimona. 2007. Poverty and environmental services: case study in Way Besai watershed, Lampung Province, Indonesia. Ecology and Society 12(2): 13. [online] URL: http://www.ecologyandsociety.org/vol12/iss2/ art13/

Tadross, M., and P. Wolski. 2010. Climate change modelling for the Pangani Basin to support the IWRM planning process. Pangani River Basin Flow Assessment. Pangani River Basin Water Board (PBWB), Moshi, Tanzania and IUCN Eastern and Southern Africa Regional Programme, Nairobi, Kenya. [online] URL: http://www.panganibasin.com/index.php/prbmp/resources/pangani climate change modelling for the pangani basin to support the iwr/

Thomas, D. B., E. A., M. Grunder, and J. K. Mburu. 1997. Soil and water conservation manual for Kenya. Ministry of Agriculture, Livestock Development and Marketing, Nairobi, Kenya. 
Turpie, J. K., C. Marais, and J. N. Blignaut. 2008. The working for water programme: evolution of a payments for ecosystem services mechanism that addresses both poverty and ecosystem service delivery in South Africa. Ecological Economics 65 (4):788-798. http://dx.doi.org/10.1016/j.ecolecon.2007.12.024

United Nations Environment Programme (UNEP). 2006. Africa environment outlook 2. Our environment, our wealth. UNEP, Nairobi, Kenya.

United Nations Framework Convention on Climate Change (UNFCCC). 2010. Report of the Conference of the Parties on its fifteenth session, held in Copenhagen from 7 to 19 December 2009. Addendum Part Two: Action taken by the Conference of the Parties at its fifteenth session. 2/CP.15 Copenhagen Accord. FCCC/ CP/2009/11/Add.1, UNFCCC Secretariat, Bonn, Germany. [online] URL: http://unfccc.int/meetings/copenhagen dec 2009/ meeting/6295/php/view/reports.php

van de Sand, I. 2004. Assessing the use of environmental service payments as a potential adaptation strategy to climate change in Cidanau watershed, Banten, Indonesia. Thesis. Imperial College London, London, UK.

van de Sand, I. 2012b. Assessing vulnerability to climate variability and change: participatory assessment approach and Kenyan case study. Studies 65, German Development Institute/Deutsches Institut für Entwicklungspolitik (DIE), Bonn, Germany. [online] URL: http://www.die-gdi.de/uploads/media/Studies 65.pdf

van de Sand, I. 2012a. Payments for ecosystem services in the context of adaptation to climate change. Ecology and Society 17 (1): 11. http://dx.doi.org/10.5751/ES-04561-170111

Msafiri, P. 2008. The opportunities and challenges of implementing PES in the water sector: a Kenyan buyer's perspective. FAO capacity building workshop on Payments for Environmental Services from agricultural landscapes, 4-6 February 2008, Dar Es Salaam, Tanzania. Food and Agricultural Organization, Rome, Italy.

Water rationing in Nairobi officially announced. 2008. Nairobi Chronicle, 16 May. [online] URL: https://nairobichronicle. wordpress.com/2008/05/16/water-rationing-in-nairobi-officiallyannounced/

Wertz-Kanounnikoff, S., B. Locatelli, S. Wunder, and M. Brockhaus. 2011. Ecosystem-based adaptation to climate change: what scope for payments for environmental services? Climate and Development 3(2):143-158. http://dx.doi.org/10.1080/17565529.2011.582277

World Bank. 2012. The international benchmarking network for water and sanitation utilities (IBNET). Energy and Water Department, World Bank, Washington, D.C., USA. [online] URL: http://www.ib-net.org/

Wunder, S. 2005. Payments for environmental services: some nuts and bolts. CIFOR Occasional Paper No. 42. Center for International Forestry Research (CIFOR), Bogor, Indonesia. [online] URL: http://www.cifor.org/publications/pdf files/OccPapers/ OP-42.pdf
Wunder, S., S. Engel, and S. Pagiola. 2008. Taking stock: a comparative analysis of payments for environmental services programs in developed and developing countries. Ecological Economics 65(4):834-852. http://dx.doi.org/10.1016/j.ecolecon.2008.03.010

Xu, Z. X., F. F. Zhao, and J. Y. Li. 2009. Response of streamflow to climate change in the headwater catchment of the Yellow River basin. Quaternary International 208(1-2):62-75. http://dx.doi. org/10.1016/j.quaint.2008.09.001 